\title{
Suitability of Aquatic Plant Fibers for Handmade Papermaking
}

\author{
Nordiah Bidin, ${ }^{1}$ Muta Harah Zakaria, ${ }^{1,2}$ Japar Sidik Bujang, ${ }^{3}$ and Nur Aznadia Abdul Aziz \\ ${ }^{1}$ Department of Aquaculture, Faculty of Agriculture, Universiti Putra Malaysia (UPM), 43400 Serdang, \\ Selangor (Darul Ehsan), Malaysia \\ ${ }^{2}$ Institute of Bioscience, Universiti Putra Malaysia (UPM), 43400 Serdang, Selangor (Darul Ehsan), Malaysia \\ ${ }^{3}$ Department of Biology, Faculty of Science, Universiti Putra Malaysia (UPM), 43400 Serdang, Selangor (Darul Ehsan), Malaysia
}

Correspondence should be addressed to Muta Harah Zakaria; muta@upm.edu.my

Received 17 January 2015; Accepted 25 April 2015

Academic Editor: Mahbub Hasan

Copyright (C) 2015 Nordiah Bidin et al. This is an open access article distributed under the Creative Commons Attribution License, which permits unrestricted use, distribution, and reproduction in any medium, provided the original work is properly cited.

\begin{abstract}
Increasing concerns for future fiber supplies in pulp and paper industries has shifted interest in nonwood sources from agriculture residues and aquatic plants. Aquatic plants with short growth cycles, in abundance, and with low lignin are a potential fiber source. Five aquatic plant species, Cyperus digitatus, Cyperus halpan, Cyperus rotundus, Scirpus grossus, and Typha angustifolia, were examined for fiber dimensions and chemical composition (cellulose, lignin) and compared with other nonwood plants. All aquatic plants possessed short (length, $0.71-0.83 \mathrm{~mm}$ ) and thin (diameter, 9.13-12.11 $\mu \mathrm{m}$ ) fibers, narrow lumen (diameter, $4.32-$ $7.30 \mu \mathrm{m}$ ), and thin cell wall (thickness, $2.25-2.83 \mu \mathrm{m}$ ) compared with most other nonwood plants. Slenderness ratio ranged from 73.77 to 89.34 with Typha angustifolia having the highest ratio. Except for Scirpus grossus, the flexibility coefficient ranged from 52.91 to 58.08. Scirpus grossus has low Runkel ratio, $0.84 \pm 0.17$. Fiber characteristics, short and thin fibers, Slenderness ratio $>60$, flexibility coefficient within 50-75, and Runkel ratio $<1$, are suitable for papermaking. Cellulose content of Cyperus rotundus (42.58 $\pm 1.32 \%)$, Scirpus grossus $(36.21 \pm 2.81 \%)$, and Typha angustifolia $(44.05 \pm 0.49 \%)>34 \%$ is suitable for pulp and papermaking. Lignin content in aquatic plants in the present study ranged $9.54-20.04 \%$ and below the wood lignin content of $<23-30 \%$ encountered in pulp and papermaking. Handmade paper sheets produced for paperboard, craft, and decorative purposes are with permissible tensile strength, breaking length, and low moisture content.
\end{abstract}

\section{Introduction}

Population growth, better literacy, and development of communication and industrialization in developing countries increase worldwide paper products demand continuously [1]. In 2005, 17.4 million metric tons $(9.27 \%)$ of nonwood fibers from 187.6 million metric tons global production of virgin pulp for paper and paperboard are produced [2]. In many countries, quantities of available wood are insufficient to meet the requirements and demands of pulp and paper especially in Mediterranean countries like Spain, Italy, and Greece [3-5]. In Malaysia, over one million tons of papers were produced in 2005 [6]. This would mean that more tropical trees need to be felled to sustain papermaking industry to meet the paper requirement and demand. To reduce the loss of rainforests, an attempt was made to find the alternative source of fiber for paper. Some alternatives have been used to replace the wood fiber with nonwood derived fibers [1] from agriculture residues such as wheat and rice straw, sorghum stalks, jute, and hemp for paper production $[7,8]$.

Another alternative source of fibers for paper production is from aquatic plants found in lakes, ditches, rivers, ponds, and estuaries. They have short life cycle, grow massively, and due to their abundance can cause problems in irrigation channels water bodies $[9,10]$. Besides, excessive growth of these aquatic plants can influence water management and ecosystem in ways such as affecting drainage, aesthetics, fishing activities, flood control, irrigation, and recreational and land values [11]. One way to control these plants is to use them as an alternative source for papermaking. Aquatic plants are nonfood plants and they have large differences in their physical and chemical characteristics [12,13]. According to Ververis et al. [5], fiber dimension, lignin, and cellulose content of nonwood plants determine their suitability for 
paper production. Under certain conditions, tearing resistance of the paper is highly dependent on fiber dimension, that is, fiber length [14]. Although the major source of fiber for paper production is from wood plant, nonwood aquatic plants with less lignin content have potentials to be used as an alternative fiber source [13].

Handmade paper industry is an environmental friendly and very promising industry for local entrepreneurship. Papers made from aquatic plants have multiple uses. They can be used for writing, food wrapping, tissue paper, and book mark and can be commercialized as value added materials for handmade crafts. Hence, the objectives of this study was to examine the fiber characteristics, derived values, and chemical composition of five aquatic plant species and compare them with other nonwood plant species that have been used to produce pulp and paper to determine their suitability for handmade papermaking. Additionally, handmade paper sheets produced of selected aquatic plants were tested for their quality with respect to tensile strength, breaking length, and moisture content.

\section{Materials and Methods}

2.1. Sample Collection. Aquatic plants, Cyperus digitatus, Cyperus halpan, Cyperus rotundus, Scirpus grossus and Typha angustifolia, found in abundance in ponds ( $02^{\circ} 59.109^{\prime}, \mathrm{E}$ $\left.101^{\circ} 41.432^{\prime}\right)$ at Universiti Putra Malaysia and wetland areas (N $02^{\circ} 59.163^{\prime}$, E $101^{\circ} 39.000^{\prime}$ ) around Selangor, Malaysia, were chosen and collected for this study. Plants were cleaned, leaves were removed, and stems were kept for determination of fiber dimension and derived values. Fresh stems were dried for determination of chemical composition and papermaking as described in detail below.

2.2. Fiber Dimension. Stems of aquatic plant were chopped into small pieces of 1 to $3 \mathrm{~cm}$ in length using a knife. One gram $(1 \mathrm{~g})$ of stems was placed in a test tube and macerated with $10 \mathrm{~mL} 33.5 \%$ nitric acid $\left(\mathrm{HNO}_{3}\right)$ and boiled in water bath at $80^{\circ} \mathrm{C}$ for 2 hours. Macerated stems containing fibers were rinsed with distilled water to remove yellow stains of $\mathrm{HNO}_{3}$ and placed in a small flask containing $50 \mathrm{~mL}$ distilled water. A drop of macerated fiber suspension was placed on microscope slide and a drop of Safranin was used to enhance the cell wall visibility. Fiber diameter, fiber length, cell wall thickness, and lumen diameter were viewed and measured, and image was captured and recorded under calibrated Axioskop NIKON compound microscope. The fiber dimensions determination was following the method of Ververis et al. [5]. All fiber dimensions were used to determine the derived values, slenderness ratio, flexibility coefficient, and Runkel ratio, following Tamolang [15] and calculated as shown below.

Slenderness ratio $=$ fiber length $(\mu \mathrm{m}) /$ fiber diameter $(\mu \mathrm{m})$.

Flexibility coefficient $=$ fiber lumen diameter $(\mu \mathrm{m}) /$ fiber diameter $(\mu \mathrm{m}) \times 100$.

Runkel ratio $=$ cell wall thickness $(\mu \mathrm{m}) /$ fiber lumen diameter $(\mu \mathrm{m}) \times 2$.
2.3. Chemical Composition. Of the five aquatic plant species, Cyperus rotundus, Scirpus grossus, and Typha angustifolia were chosen based on their fiber dimensions and derived values (lower and higher values as determined from Section 2.2 above) for evaluation of their chemical composition. The stems were ground and sieved with $250 \mu \mathrm{m}$ sieve. Two grams $(2 \mathrm{~g})$ of sample was weighted and placed in cellulose thimble and the cellulose was extracted by using Soxhlet apparatus with 2:1 alcohol acetone solution. After 4 hours of extraction, sample was placed in desiccators until obtaining the constant weight. The cellulose content determination was performed in triplicates. The cellulose, hemicelluloses, and lignin contents were calculated based on the formula described by Moubasher et al. [16] as follows.

$$
\begin{aligned}
& \text { Cellulose content }=(Y-Z) / W \times 100 . \\
& \text { Hemicelluloses content }=(X-Y) / W \times 100 . \\
& \text { Lignin content }=(Z-V) / W \times 100 .
\end{aligned}
$$

$V$ = weight of glass thimble $(\mathrm{g}), \mathrm{W}=$ weight of extractivefree sample (g), $Y$ = weight of glass thimble with sample after being treated with $\mathrm{KOH}(\mathrm{g})$, and $Z$ = weight of the glass thimble with sample after being hydrolyzed with $\mathrm{H}_{2} \mathrm{SO}_{4}(\mathrm{~g})$.

2.4. Pulping and Papermaking. Hundred gram (100 g) of dried stems of Cyperus rotundus, Scirpus grossus, and Typha angustifolia was cooked with $20 \mathrm{~g}$ sodium carbonate $\left(\mathrm{Na}_{2} \mathrm{CO}_{3}\right)$ and $2 \mathrm{~L}$ of water at $140^{\circ} \mathrm{C}$ for 2 hours by using induction cooker. After 2 hours, the cooked samples were cleaned under water flow to remove the chemical and blended by using electronic blender. $50 \mathrm{~mL}$ of starch solution $(1 \mathrm{~g}$ of starch diluted in $1000 \mathrm{~mL}$ of distilled water) was then added to the pulp in an electronic mixture. Mould and deckle pouring method and couching technique was used in the papermaking process according to Hiebert [17].

2.5. Paper Quality. Moisture content of the produced paper sheet was determined by placing one gram (1 g) of paper sheet on AD-4715 Infrared Moisture Determination Balance. The tensile strength and breaking length were tested for the paper sheet strips by using modified TAPPI (Technical Association of the Pulp and Paper Industry) 494 om-06 [18] standard method of tensile properties for paper and paperboard. Tensile strength and breaking length were calculated as shown below.

Tensile strength $(\mathrm{kN} / \mathrm{m})=$ Maximum breaking force $(\mathrm{kN}) /$ width of paper strip $(\mathrm{m})$.

Breaking length $(\mathrm{km})=102000 \times$ (Tensile strength $(\mathrm{kN} / \mathrm{m})$ /grammage $\left(\mathrm{g} / \mathrm{m}^{2}\right)$.

2.6. Statistical Analysis. One way analysis of variance (ANOVA) followed by post hoc Duncan's multiple range test $(p<0.05)$ were conducted using SPSS program to compare aquatic plants species fiber dimensions, derived values, chemical composition, tensile strength, and breaking length. Principle Component Analysis (PCA) based on Bray Curtis similarity index was carried out using XLSTAT software 
(Windows version 2013) to obtain the relationship between fiber dimensions, derived values, and chemical composition of aquatic plant species in this study with other nonwood plant species that have been used to produce different type of papers.

\section{Results and Discussion}

3.1. Fiber Dimensions and Derived Values. The fiber lengths of the aquatic plants ranged from 0.71 to $0.83 \mathrm{~mm}$ and are relatively shorter than those of other nonwood plants (Table 1). Of the five species, Scirpus grossus possessed longer fiber length $(0.83 \pm 0.02 \mathrm{~mm})$, wide fiber diameter $(12.11 \pm$ $0.98 \mu \mathrm{m})$, lumen diameter $(7.30 \pm 0.89 \mu \mathrm{m})$, higher flexibility coefficient $(58.08 \pm 4.07)$, and low Runkel ratio $(0.84 \pm 0.17)$. Fiber length of Scirpus grossus is comparable with crop plants, Zea mays $(0.88 \mathrm{~mm})$. Besides fiber length, fiber diameter, lumen diameter, and cell wall thickness of nonwood plants also varied depending on the plant species and the parts (leaves, stems) from which the fibers are derived (Table 1) and this supported the observation made by Ilvessalo-Pfaffli [19]. As a comparison with hard-wood plant such as Populous tremuloides for kraft pulp, the fiber lengths are longer, 1.0$1.3 \mathrm{~mm}$, and are reported to be suitable for coated paper production [20]. However, longer fiber length tends to give less fine of sheet structure [21, 22].

Derived values (slenderness ratio, flexibility coefficient, and Runkel ratio) measure the ability of fibers to bind each other in the paper sheet. Slenderness ratio for aquatic plant species studied ranged from 77 to 89.34 , a ratio $>60$ which is attributed to the thin fibers (cf. with other nonwood plants, Table 1) suitable for producing high quality paper [5]. A combination of short and thin fibers usually will produce a good slenderness ratio, which is related to tearing resistance, paper sheet density, and pulp digestibility [28]. Comparatively, these values are close to slenderness ratio of 69.17-81.07 of Hibiscus cannabinus used to produce quality paper [29]. The trend of flexibility coefficient categorically placed Scirpus grossus (58.08) as the highest followed by Cyperus halpan (53.54) and Cyperus digitatus (52.91) and these values are relatively high compared with other aquatic plant, Arundo donax internode (49.20), commercial plant Bambusa tulda stalk (20.29), and crops plant of Saccharum sp. baggase (29.29) and are comparable with Zea mays residue (54.27) [5, 25-27]. Except for Scirpus grossus, Cyperus halpan, and Cyperus digitatus the flexibility coefficient (52.91-58.08) of aquatic plant species is within the preferable flexibility coefficient range of 50-75 [30]. Runkel ratio is good in Scirpus grossus $(0.84 \pm 0.17)$ and Cyperus digitatus (1.06 \pm 0.14 ) compared with crop plants, Saccharum sp. (2.46) and commercial plant, Bambusa tulda (3.93) [25, 27]. The Runkel ratio $>1$ (e.g., $1.52 \pm 0.18$ as in Typha angustifolia) indicated that it is less flexible and stiffer and that it forms bulkier paper [5]. Low Runkel ratio and high fiber length resulted in good pulp strength properties [31]. Runkel ratio $<1$ is related to high flexibility coefficient [32] and gives good mechanical strength properties to the paper produced [28].

The principal component analysis (PCA) was performed to assess similarity in the fiber characteristics and derived

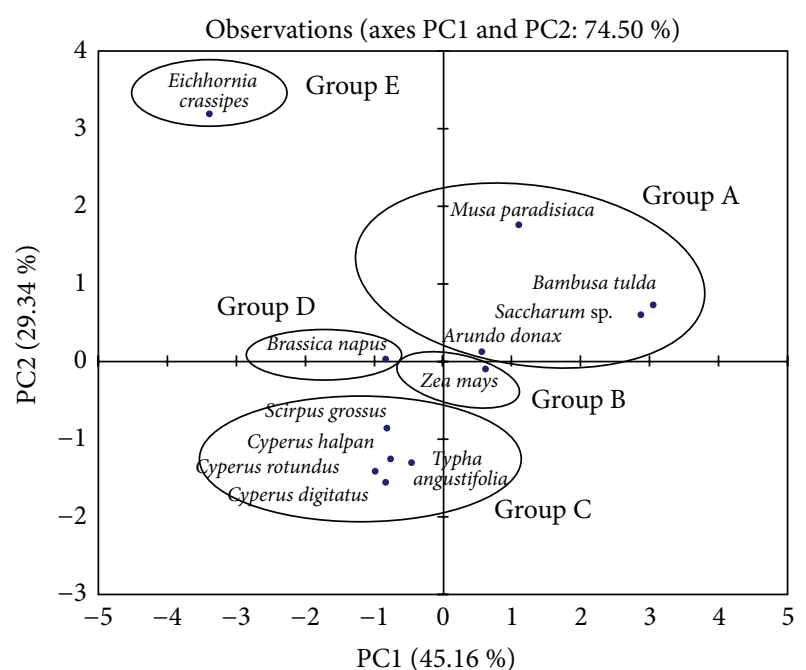

FIgURE 1: Principal component analysis (PC1 and PC2) of five aquatic plant species compared with other nonwood plant species based on their fiber dimensions and derived values.

values (slenderness ratio, flexibility coefficient, and Runkel ratio) of the aquatic plant species with other nonwood plants (Table 1) that have been tested for paper production (Table 2). The obtained results based on Bray-Curtis similarity index at $50 \%$ similarity showed the total variance of the first two components is $74.50 \%$ ( $\mathrm{PCl}$ has a total variance of $45.16 \%$ and PC2 29.34\%) and the species were clustered into five distinct groups (A, B, C, D, and E, Figure 1). Aquatic plant species, Cyperus digitatus, Cyperus halpan, Cyperus rotundus, Scirpus grossus, and Typha angustifolia, are clustered in only one group, C, independent of four other nonwood plant species, group A (Musa paradisiaca, Bambusa tulda, Saccharum sp., and Arundo donax), group B (Zea mays), group D (Brassica napus), and group E (Eichhornia crassipes). Species in group $\mathrm{B}, \mathrm{D}$ and $\mathrm{E}$ are suitable for production of writing or printing paper [5], composites and paperboard [22] and fiber plate, rigid cardboard and cardboard paper [26] (Table 2). According to Enayati et al. [1] and Kasmani et al. [33], a combination of nonwood/softwood and hardwood fibers can be promising and can have potential in papermaking.

3.2. Chemical Composition. Among the species studied, Typha angustifolia possessed comparatively higher percentages of cellulose and hemicelluloses content, $44.05 \pm 0.49 \%$ and $54.84 \pm 4.27 \%$, respectively. The cellulose content of all aquatic plant species was high and comparable with vegetable plants, Brassica napus (34.50\%) and other aquatic plants, Arundo donax (36.70\%), and Typha (pati) (36.80\%) (Table 3 ). In addition, the percentage of cellulose content $>40 \%$ was comparable with Hibiscus cannabinus [5], used to produce quality paper [29]. The holocellulose, a combination of cellulose and hemicellulose amounts to $>65-70 \%$ of reported plant dry weight [34]. The cellulose content $>34 \%$ indicates the plants are suitable for pulp and paper manufacturing. Cellulose content affects the strength and makes the fiber strand liable to natural and synthetic dye binding while 


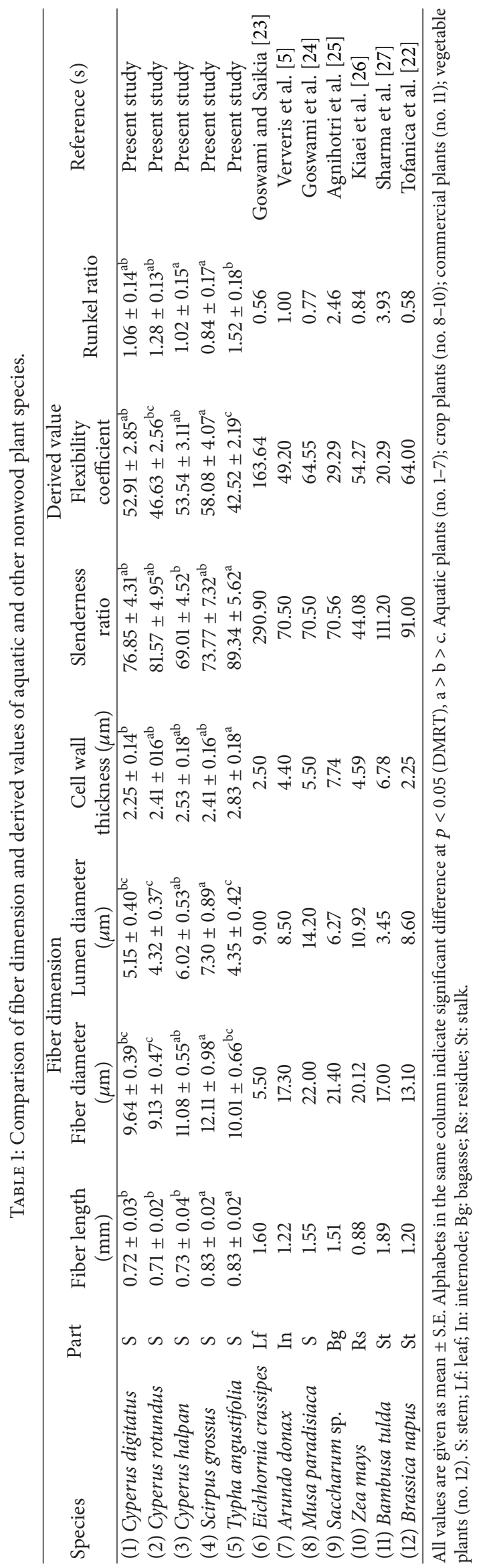




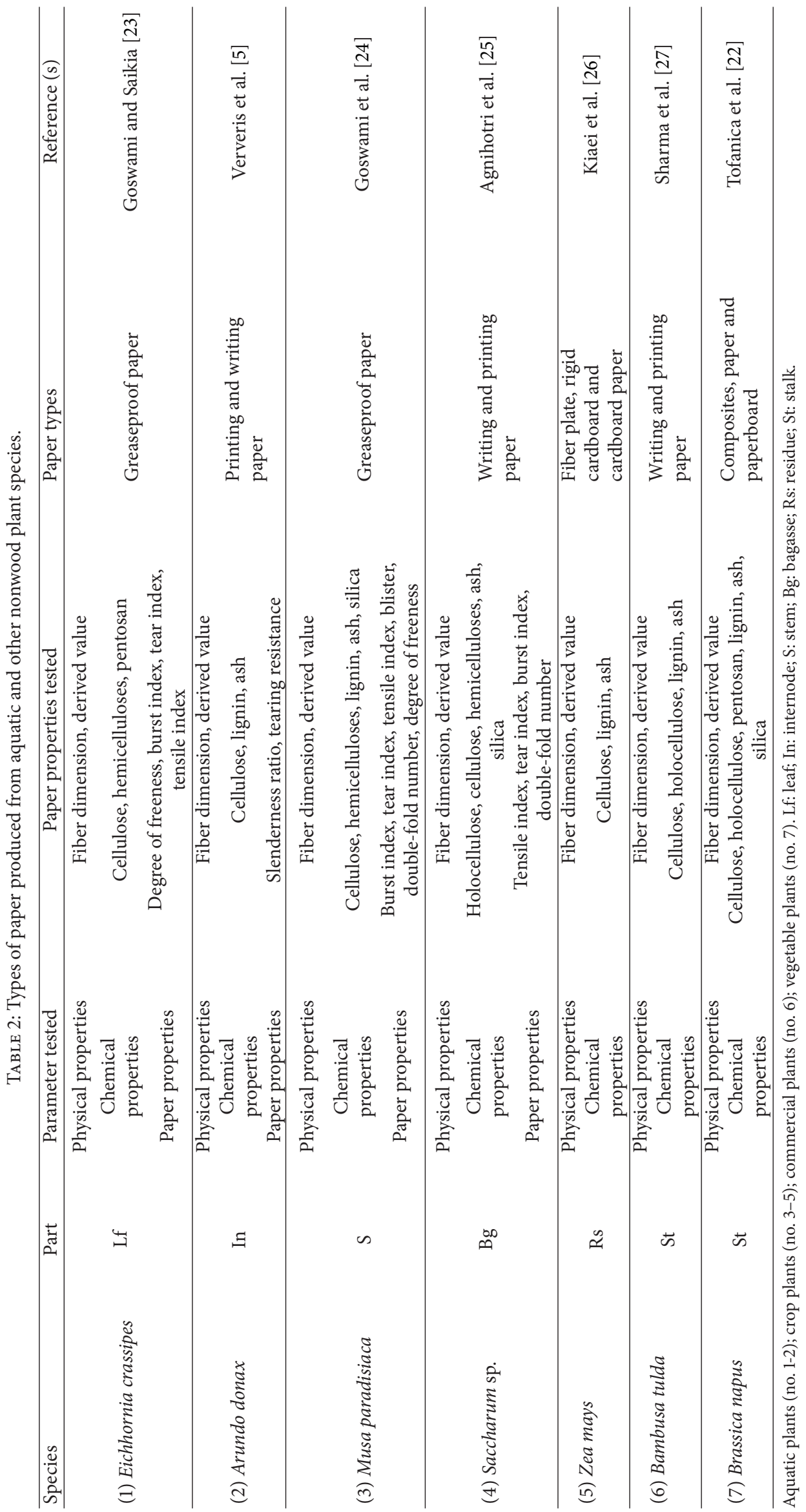




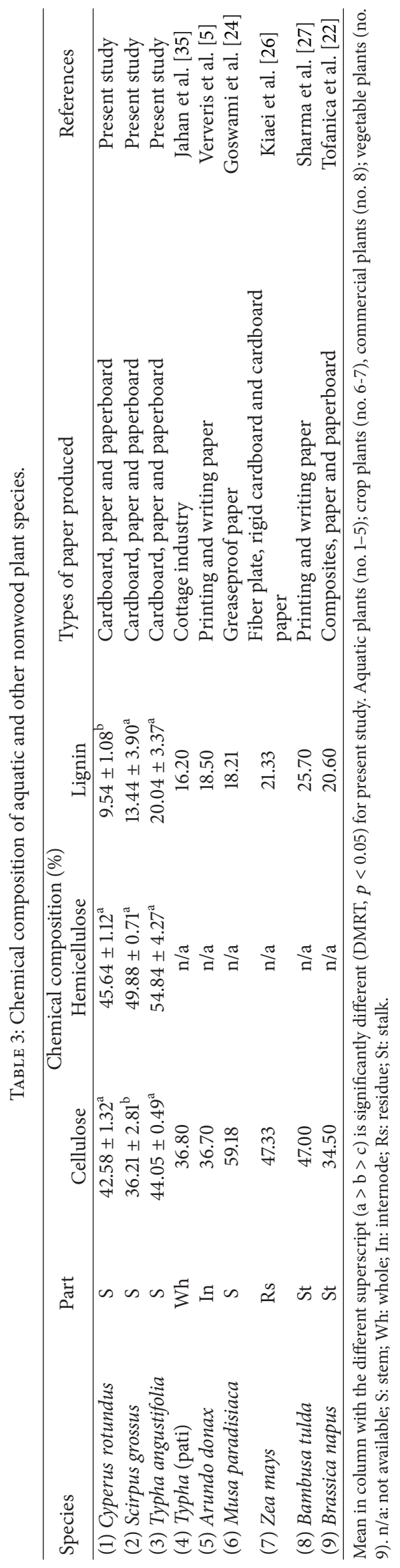


TABLE 4: Measurement for determination of paper quality of selected aquatic plant species.

\begin{tabular}{lccc}
\hline Species & Tensile strength $(\mathrm{kN} / \mathrm{m})$ & Breaking length $(\mathrm{m})$ & Moisture content $(\%)$ \\
\hline Cyperus rotundus & $1.69 \pm 0.18^{\mathrm{a}}$ & $731.68 \pm 72.75^{\mathrm{a}}$ & $10.11 \pm 0.04^{\mathrm{b}}$ \\
Scirpus grossus & $1.52 \pm 0.21^{\mathrm{a}}$ & $612.39 \pm 34.05^{\mathrm{a}}$ & $13.08 \pm 0.41^{\mathrm{a}}$ \\
Typha angustifolia & $0.94 \pm 0.20^{\mathrm{b}}$ & $410.11 \pm 82.85^{\mathrm{b}}$ & $13.13 \pm 0.11^{\mathrm{a}}$ \\
\hline
\end{tabular}

All values are given as mean \pm S.E. Different alphabets in the same column of parameter indicate significant difference at $p<0.05$; that is, a $>$.

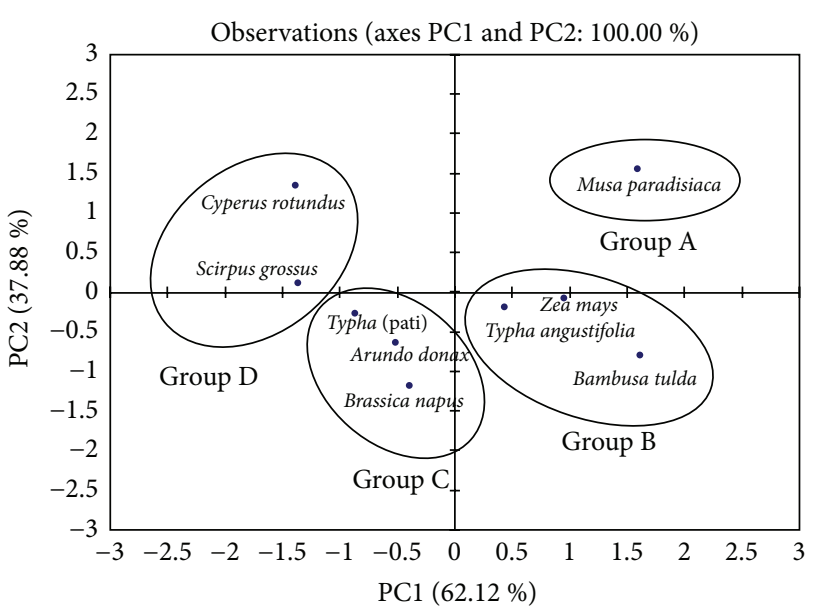

FIGURE 2: Principal component analysis (PC1 and PC2) of three aquatic plant species compared with other nonwood plant species based on their cellulose and lignin composition.

hemicelluloses is responsible for the water absorption by plant fibers and reduces internal fiber stress.

Lignin content was higher in Typha angustifolia (20.04 \pm $3.37 \%)$ followed by Scirpus grossus (13.44 $\pm 3.90 \%)$ and it was lowest in Cyperus rotundus $(9.54 \pm 1.08 \%)$. Cyperus rotundus has the lower lignin content compared with Typha (pati) (16.20\%) [35], Arundo donax (18.50\%) [5], Musa paradisiaca (18.21\%) [24], and Zea mays (21.33\%) [26]. Moreover, lignin content in Typha angustifolia was similar with Brassica napus (19.21-20\%) [22, 36]. The lignin content for these studied species was lower than wood fiber lignin content of 23-30\% for pulp and papermaking [13]. Dutt and Tyagi [28] reported that lignin content in Eucalyptus sp. was $>25 \%$. However, all three species can be pulped in one-third of the time needed for hardwoods and softwood due to the lower lignin content [5]. Lignin was considered undesirable component during pulping and papermaking due to its unstable color and for being relatively dark and its hydrophobic surface caused unfavorable interfiber bond formation of hemicelluloses and cellulose [37].

Comparison of chemical composition of aquatic plants and other nonwood plants (vegetables, crops, and commercial plants) with their type of paper is shown in Table 3. The present study data and available data on nonwood plants were ordinated with PCA using lignin and cellulose composition. The biplot generated four main clusters (Figure 2). Aquatic plants are in two clusters: Typha angustifolia is in group B with Zea mays and Bambusa tulda while Cyperus rotundus and Scirpus grossus are in group D. Based on fiber characteristics, cellulose and lignin content, plants in group $\mathrm{B}$, can be utilized for production of fiber plate, rigid cardboard, cardboard paper, writing and content of printing paper (Table $3,[25,27]$ ). In group $C$, paper sheets derived from fibers and cellulose from these plants had been tested and were suitable for handmade paper in the cottage industry, composites, paperboard, and writing and printing paper (Table 3, $[5,22,35])$ for decorative purposes.

3.3. Paper Quality. Cyperus rotundus has the highest tensile strength $(1.69 \pm 0.18 \mathrm{kN} / \mathrm{m})$ and breaking length $(731.68 \pm$ $72.75 \mathrm{~m}$ ) (Table 4). The tensile strength of paper sheets produced from aquatic plants, Cyperus rotundus, Scirpus grossus, and Typha angustifolia, in this present study is in the range of $0.94-1.69 \mathrm{kN} / \mathrm{m}$ and this reflected the intimate structure of paper [38]. Its individual fibers, their arrangement, and the extent to which they are bonded to each other are key factors which contribute to tensile strength. Long fibers generally produced paper with higher tensile strength properties than paper from short fiber. However, interfiber bonding is considered as the most important factor contributing to the paper tensile strength. Jeyasingam [39] mentioned that breaking length for Hibiscus cannabinus was $4000 \mathrm{~m}$ ten times higher than the present study range of $410.11-731.68 \mathrm{~m}$. Jahan et al. [40] also found that the breaking length of nonwood raw materials such as jute, cotton stalks, corn stalks, bagasse, saccharum, rice straw, and wheat straw varies in the range of 5511-7550 $\mathrm{m}$. In addition, the breaking length values are in the range of 3650-5300 $\mathrm{m}$ for different types of paper, that is, offset, rag bond, and news print papers [38]. Hierarchically, paper moisture content was Typha angustifolia (13.13 \pm $0.11 \%)>$ Scirpus grossus $(13.08 \pm 0.41 \%)>$ Cyperus rotundus $(10.11 \pm 0.042 \%)$. Moisture in paper varies from $2 \%$ to $12 \%$ depending on relative humidity, type of pulp used, degree of refining, and chemical used. Ideally a good quality paper possessed properties of comparatively high tensile strength and breaking length and lower moisture content. Other than being used for craft, wrapping, or decorative purposes, fibers derived from aquatic plant species as in this study may be suitable for newsprint production as their tensile strength is in the range of newsprint paper $(0.90-1.79 \mathrm{kN} / \mathrm{m})$ as reported by Caulfield and Gunderson [38].

\section{Conclusion}

Scirpus grossus, Cyperus rotundus, and Typha angustifolia are suitable aquatic plants species for papermaking based on their fiber characteristics, chemical composition, and physical properties. An abundance and availability of these plants can provide sustainable large biomass as raw fibers for pulp 
and paper production. Handmade paper sheets produced for paperboard, writing, and printing paper used for craft, wrapping, and decorative purposes are with permissible tensile strength, breaking length, and low moisture content.

\section{Conflict of Interests}

The authors declare that there is no conflict of interests regarding the publication of this paper.

\section{Acknowledgments}

This study was funded under ScienceFund grant by Ministry of Science and Technology and Innovation Malaysia (MOSTI) under Science Fund Project (04-01-04-SF1184) entitled Utilization of Aquatic Macrophytes for Papermaking. Logistics and facilities were provided by the Faculty of Agriculture, Faculty of Environmental Studies, and Faculty of Engineering, Universiti Putra Malaysia.

\section{References}

[1] A. A. Enayati, Y. Hamzeh, S. A. Mirshokraie, and M. Molaii, "Papermaking potential of canola stalks," BioResources, vol. 4, no. 1, pp. 245-256, 2009.

[2] B. J. Bowyer, R. Shmulsky, and J. G. Haygreen, "Forest products and wood science," in An Introduction, Blackwell Publishing, New York, NY, USA, 5th edition, 2007.

[3] M. Judt, "Non-wood plant fibres, will there be a come-back in paper-making?” Industrial Crops and Products, vol. 2, no. 1, pp. 51-57, 1993.

[4] L. Paavilainen and R. Torgilson, "Reed canary grass. A new nordic papermaking fiber," in Proceedings of the TAPPI Pulping Conference, pp. 611-618, San Diego, Calif, USA, 1994.

[5] C. Ververis, K. Georghiou, N. Christodoulakis, P. Santas, and R. Santas, "Fiber dimensions, lignin and cellulose content of various plant materials and their suitability for paper production," Industrial Crops and Products, vol. 19, no. 3, pp. 245-254, 2004.

[6] J. M. Roda and S. S. Rathi, Feeding China's Expanding Demand for Wood Pulp: A Diagnostic Assessment of Plantation Development, Fiber Supply, and Impacts on Natural Forests in China and in the South East Asia Region, Center for International Forestry Research (CIFOR), Bogor, Indonesia, 2006.

[7] P. Rousu, P. Rousu, and J. Anttila, "Sustainable pulp production from agricultural waste," Resources, Conservation and Recycling, vol. 35, no. 1-2, pp. 85-103, 2002.

[8] A. Ashori, "Nonwood fibers-a potential source of raw material in papermaking," Polymer-Plastics Technology and Engineering, vol. 45, pp. 131-134, 2006.

[9] A. Banerjee and S. Matai, "Composition of Indian aquatic plants in relation to utilization as animal forage," Journal Aquatic Plants Management, vol. 28, pp. 69-73, 1990.

[10] L. Lancar and K. Krake, "Aquatic weeds and their management," in Proceedings of the Workshop on Management of Aquatic Weeds, International Commission on Irrigation and Drainage, Punjab, India, 2002.

[11] D. Pimentel, L. Lach, R. Zuniga, and D. Morrison, "Environmental and economic costs of non-indigenous species in the United States," BioScience, vol. 50, no. 1, pp. 53-65, 2000.

[12] R. W. Hurter, "Nonwood plant fiber characteristics," Agricultural Residues, pp. 1-4, 1997.
[13] R. W. Hurter and F. A. Riccio, "Why CEOS don't want to hear about nonwoods-or should they?" in Proceedings of the TAPPI Proceedings, NA Non-Wood Fiber Symposium, pp. 1-11, Atlanta, Ga, USA, 1998.

[14] R. S. Seth and D. H. Page, "Fiber properties and tearing resistance," Tappi Journal, vol. 71, no. 2, pp. 103-107, 1988.

[15] F. N. Tamolang, "Properties and utilization of Philippine erect bamboos," Forpridge Digest, vol. 9, pp. 14-27, 1980.

[16] M. H. Moubasher, S. H. Abdel-Hafez, and A. M. Mohanram, "Direct estimation of cellulose, hemicellulose, lignin," Journal of Agricultural Research, vol. 46, pp. 1467-1476, 1982.

[17] H. Hiebert, Papermaking with Garden Plants and Common Weeds, Storey Publishing, 2006.

[18] Technical Association of the Pulp and Paper Industry (TAPPI), Tensile Properties of Paper and Paperboard (Using Constant Rate of Elongation Apparatus) (T 494 0m-06), U.S.A. TAPPI Press, 2006.

[19] M.-S. Ilvessalo-Pfaffli, "Identification of papermaking fibers," in Fiber Atlas, T. E. Timell, Ed., Springer Series in Wood Science, pp. 165-263, The Finnish Pulp and Paper Research Institute, Espoo, Finland, 1995.

[20] R. A. Horn, "Morphology of pulp fiber from hardwoods and influence on paper strength," in Research Paper Forestry Product Laboratory-312, pp. 1-8, US Department of Agriculture, Forest Service, Forest Products Laboratory, Madison, Wis, USA, 1978.

[21] J. Shakhes, F. Zeinaly, M. A. B. Marandi, and T. Saghafi, “The effects of processing variables on the soda and soda-AQ pulping of Kenaf bast fiber," BioResources, vol. 6, no. 4, pp. 4626-4639, 2011.

[22] B. M. Tofanica, E. Cappelletto, D. Gavrilescu, and K. Mueller, "Properties of rapeseed (Brassica napus) stalks fibers," Journal of Natural Fibers, vol. 8, no. 4, pp. 241-262, 2011.

[23] T. Goswami and C. N. Saikia, "Water hyacinth-a potential source of raw material for greaseproof paper," BioResource Technology, vol. 50, no. 3, pp. 235-238, 1994.

[24] T. Goswami, D. Kalita, and P. G. Rao, "Greaseproof paper from banana (Musa paradisica L.) pulp fibre," Indian Journal of Chemical Technology, vol. 15, no. 5, pp. 457-461, 2008.

[25] S. Agnihotri, D. Dutt, and C. H. Tyagi, "Complete characterization of bagasse of early species of Saccharum officinerum-Co 89003 for pulp and paper making," BioResources, vol. 5, no. 2, pp. 1197-1214, 2010.

[26] M. Kiaei, A. Samariha, and J. E. Kasmani, "Characterization of biometry and the chemical and morphological properties of fibers from bagasse, corn, sunflower, rice and rapeseed residues in iran," African Journal of Agricultural Research, vol. 6, no. 16, pp. 3762-3767, 2011.

[27] M. Sharma, C. I. Sharma, and Y. B. Kumar, "Evaluation of fiber characteristics in some weeds of Arunachal Pradesh, India for pulp and papermaking," Research Journal of Agricultural and Forestry Sciences, vol. 1, no. 3, pp. 15-21, 2013.

[28] D. Dutt and C. H. Tyagi, "Comparison of various Eucalyptus species for their morphological, chemical, pulp and paper making characteristics," Indian Journal of Chemical Technology, vol. 18, no. 2, pp. 145-151, 2011.

[29] A. A. Mossello, J. Harun, H. Resalati, R. Ibrahim, S. R. F. Shmas, and P. M. Tahir, "New approach to use of kenaf for paper and paperboard production," BioResources, vol. 5, no. 4, pp. 21122122, 2010.

[30] I. Bektaş, A. Tutuş, and H. Eroğlu, "A study of the suitability of calabrian pine (Pinus brutia ten.) for pulp and paper 
manufacture," Turkish Journal of Agriculture and Forestry, vol. 23, no. 7, pp. 589-597, 1999.

[31] J. Shakhes, M. A. B. Marandi, F. Zeinaly, A. Saraian, and T. Saghafi, "Tobacco residuals as promising lignocellulosic materials for pulp and paper industry," BioResources, vol. 6, no. 4, pp. 4481-4493, 2011.

[32] O. F. Olotuah, "Suitability of some local bast fibre plants in pulp and paper making," Journal of Biological Sciences, vol. 6, no. 3, pp. 635-637, 2006.

[33] J. E. Kasmani, A. Samariha, and M. Kiaei, "Investigation on pulping potential of iranian rapeseed residue in the paper industrial," World Applied Sciences Journal, vol. 12, no. 11, pp. 1996-2001, 2011.

[34] J. A. F. Benazir, V. Manimekalai, P. Ravichandran, R. Suganthi, and D. C. Dinesh, "Properties of fibres/culm strands from mat sedge-Cyperus pangorei Rottb," BioResources, vol. 5, no. 2, pp. 951-967, 2010.

[35] M. S. Jahan, M. K. Islam, D. A. N. Chowdhury, S. M. I. Moeiz, and U. Arman, "Pulping and papermaking properties of pati (Typha)," Industrial Crops and Products, vol. 26, no. 3, pp. 259264, 2007.

[36] R. Housseinpour, A. Jahan Latibari, R. Farnood, P. Fatehi, and S. Javad Sepiddehdam, "Fiber morphology and chemical composition of rapeseed (Brassica napus) stems," International Association of Wood Anatomists Journal, vol. 31, no. 4, pp. 457464, 2010.

[37] M. A. Hubbe and C. Bowden, "Handmade paper: a review of its history, craft, and science," BioResources, vol. 4, no. 4, pp. 17361792, 2009.

[38] D. F. Caulfield and D. E. Gunderson, "Paper testing and strength characteristics," in Proceedings of the TAPPI Proceedings of the Paper Preservation Symposium, pp. 31-40, TAPPI Press, Atlanta, Ga, USA, 1988.

[39] J. T. Jeyasingam, "A summary of special problems and considerations related to non-wood pulping worldwide," in Proceedings of the Pulping Conference, pp. 571-579, TAPPI Press, Atlanta, Ga, USA, 1988.

[40] M. S. Jahan, B. G. Gunter, and A. Rahman, "Substituting wood with nonwood fibers in papermaking," in A Win-Win Solution for Bangladesh. Bangladesh Development Research Center (BDRC), pp. 1-18, Bangladesh Press, 2009. 

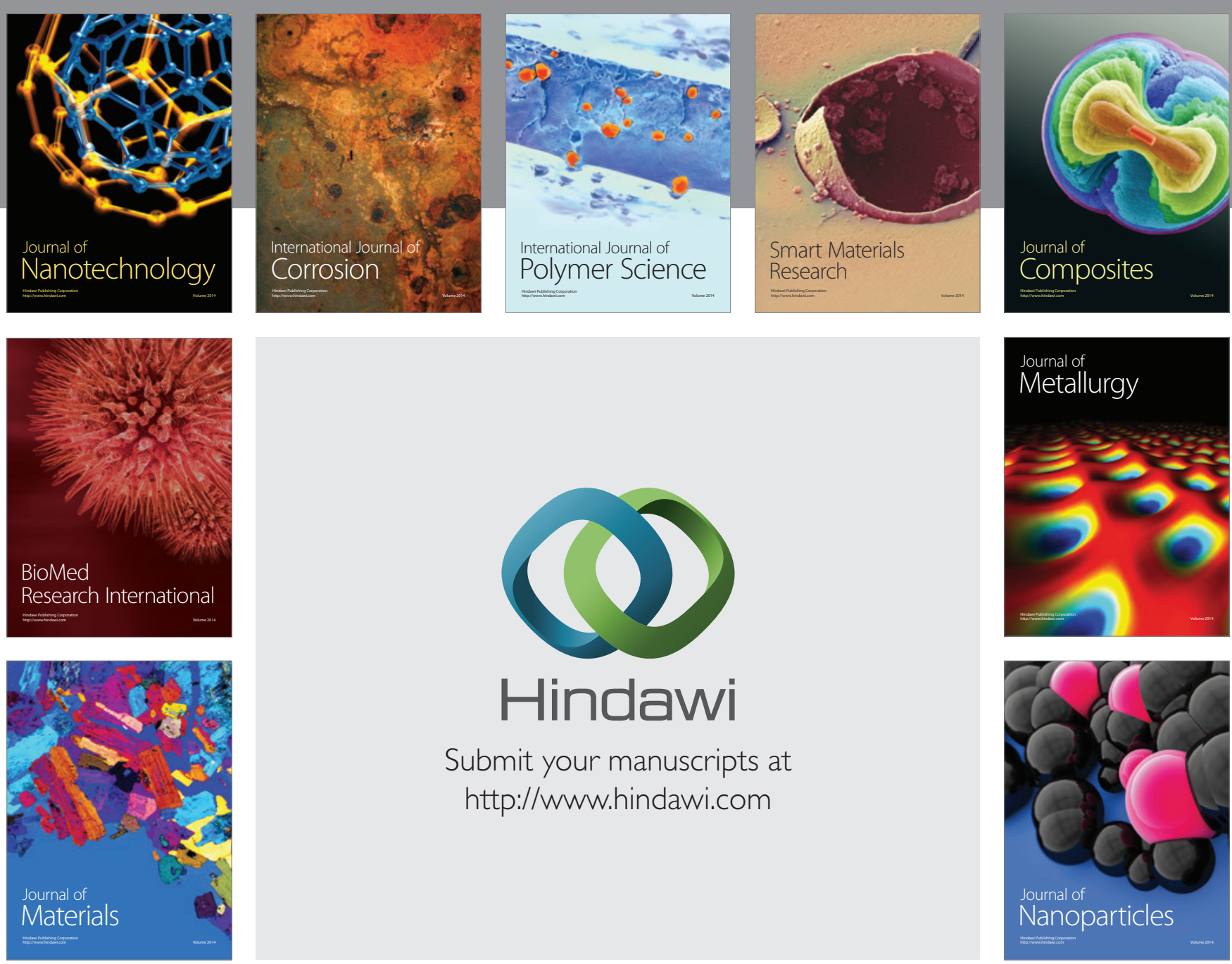

Submit your manuscripts at http://www.hindawi.com
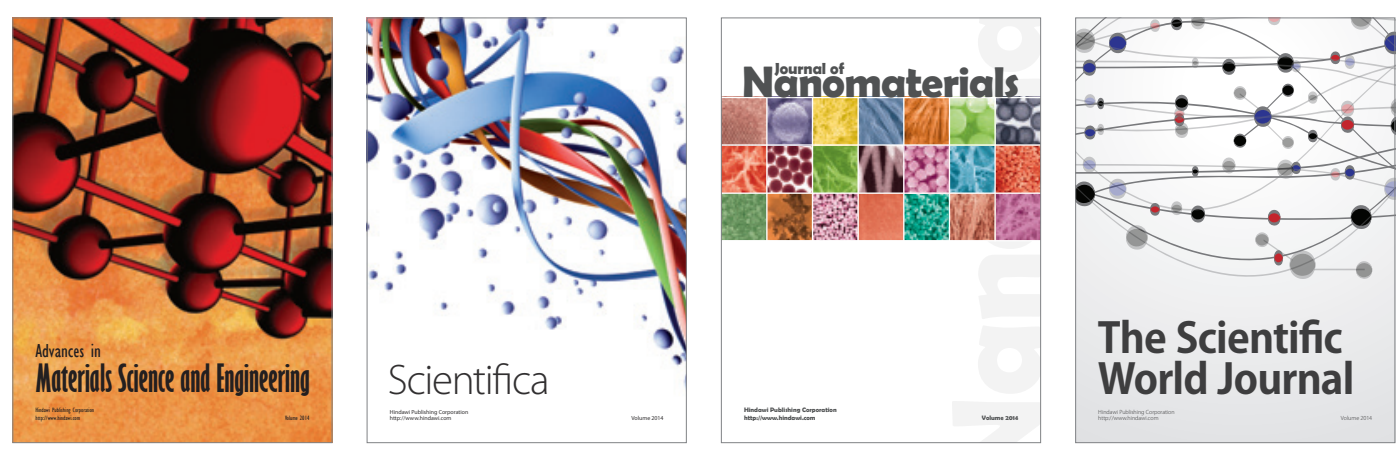

\section{The Scientific World Journal}
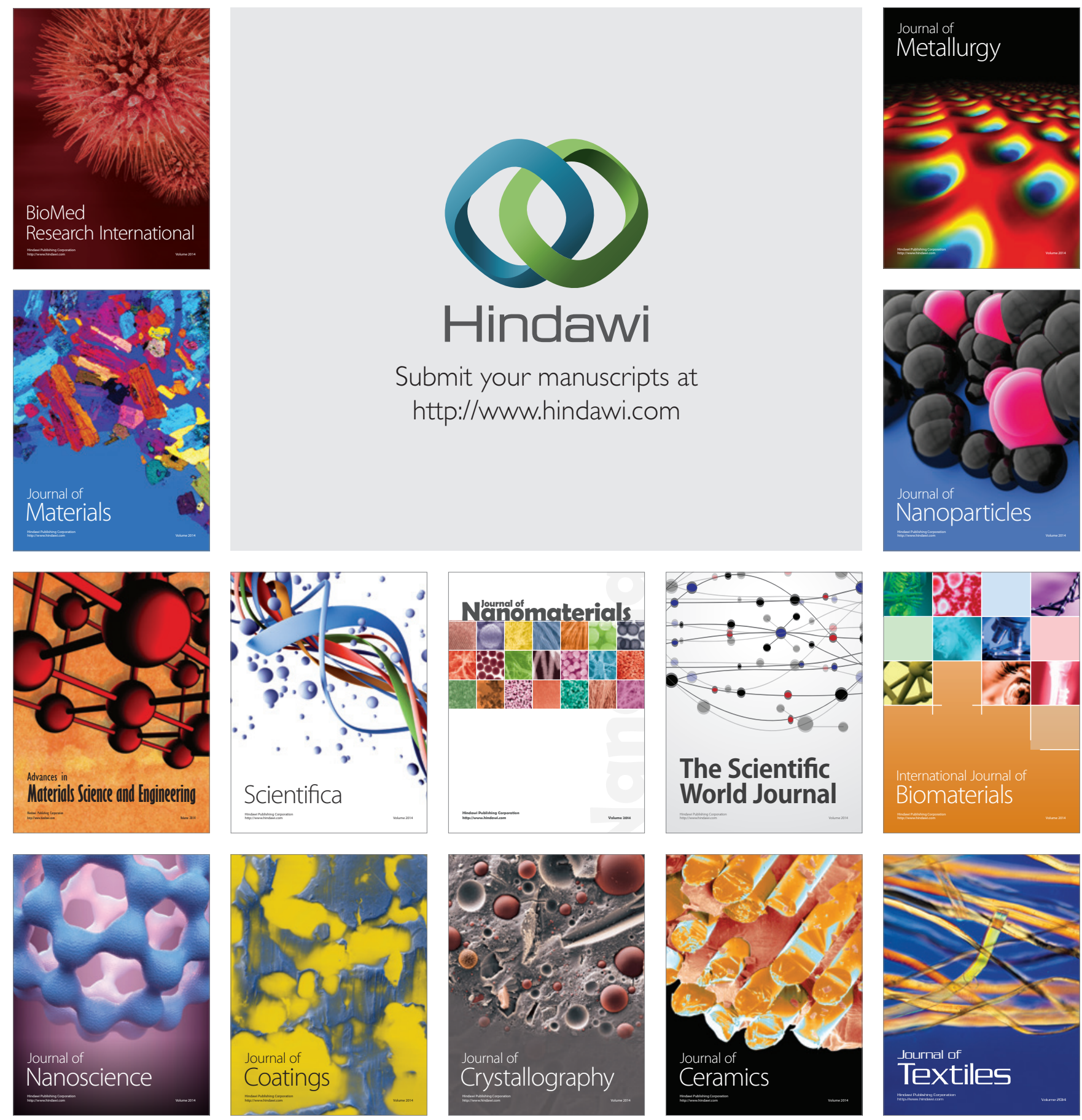